\title{
O STF e a Cláusula de Barreira: entre as experiências e suas projeções
}

\author{
The STF and the Barrier Clause: between experiences and projections
}

Diogo Rais

Pedro Henrique Espagnol de Farias

\begin{abstract}
Resumo: O tema das cláusulas de barreira e de desempenho partidário é recorrente em diversas arenas, levantando intensos debates sobre sua adoção, seu método e sua aplicação. Mas neste artigo, por um estudo essencialmente descritivo, pretende-se abordar os debates travados sobre o tema tanto no Congresso Nacional quanto no Supremo Tribunal Federal, se esforçando para promover um diálogo intertemporal diante dessas duas Instituições brasileiras. Ao final, buscamos trazer o posicionamento de cada Ministro do STF que tenha se manifestado sobre o tema, seja por meio de seus votos, seja por meio de manifestações públicas em obras acadêmicas ou entrevistas.
\end{abstract}

Palavras-chave: Cláusula de barreira. Cláusula de desempenho. Supremo Tribunal Federal. Reforma Política.

\begin{abstract}
The matter on the election threshold is frequent in many arenas of the political debate, raising discussions on its adoption, method and enforcement. In the present article, though, by means of a descriptive study, we pretend to address the debates by the National Congress and Supreme Court point of view, endeavouring to foster an intertemporal dialogue before these two Brazilian Institutions. In the end, we look forward to bring the positioning of each Justice of the Supreme Court that has expressed their opinion on the matter, through their votes, as well as on public demonstrations in academic texts or even interviews.
\end{abstract}

Keywords: Election threshold. Supreme Court. Political Reform.

Artigo recebido em 1 jul. 2017 e aprovado em 26 set. 2017. 


\section{Introdução}

$\mathrm{O}$ artigo se estrutura em três seções temporais tendo por foco a cláusula de barreira: passado, presente e futuro.

A primeira parte será dedicada à descrição das experiências antigas do tema no Supremo Tribunal Federal, conectando à atualidade da discussão no Congresso Nacional, para ao final, apresentar descrição sobre as manifestações públicas dos Ministros que compõem atualmente aquela Corte, e quem sabe, a partir daqui, apresentar alguma tendência sobre o futuro do tema, para o caso da cláusula de barreira bater, novamente, às portas do Supremo Tribunal Federal.

\section{O Passado}

Partindo da obra de Dworkin (2007), "Uma questão de princípio”, mais precisamente diante da teoria do "romance em cadeia", pela qual não se nega ao intérprete sua atividade criativa, porém se exige coerência diante da análise dos precedentes, é que propomos a análise das decisões sobre o tema no âmbito do Supremo Tribunal Federal. É como se houvesse a escrita de um único romance produzida por várias mãos ao longo do tempo, cujos capítulos (no caso, precedentes) deveriam ser conectados mesmo que escritos por autores muito diferentes.

Em outras palavras, Dworkin (2007) traz as diretrizes da interpretação jurídica aos moldes da estrutura de um livro, no qual os capítulos fazem parte de um enredo maior, e por isso, devem apresentar coerência entre si. É nessa toada que esta seção considera a jurisprudência sobre as cláusulas de barreira e desempenho como um romance à parte, em que cada caso examinado constitui um capítulo.

Coloca-se, então, como questão de fundo, a importância da coerência nos precedentes da jurisdição constitucional ${ }^{1}$, buscando a segurança jurídica, imparcialidade e igualdade, necessárias à estabilidade das relações sociais, além da concatenação interna de seus argumentos, o que implica diretamente na força representativa e institucional de seus julgados.

Embora a aplicação e o fortalecimento da teoria dos precedentes judiciais sejam mais comuns nos países de common law, é possível identificar

\footnotetext{
${ }^{1} \mathrm{O}$ art. 926, do CPC, inclusive, positiva o dever de coerência da Corte frente à sua jurisprudência.
} 
seu fortalecimento recente no Brasil, sobretudo a partir do Novo Código de Processo Civil ${ }^{2}$, em vigor há mais de um ano.

Para a elaboração desta seção foi fundamental a utilização dos estudos desenvolvidos por ocasião de monografia apresentada à Escola de Formação da Sociedade Brasileira de Direito Público (DE FARIAS, 2017), e, na busca de coerência, apresentam-se aqui algumas notas metodológicas.

Questão jurídica (quaestio iuris), conforme utilizada aqui, foi considerada como a principal indagação respondida pela decisão judicial, guiando todo o raciocínio jurídico desenvolvido no caso analisado. Vale mencionar, no entanto, que não se trata, necessariamente, da mesma questão-problema suscitada pela parte em sua petição inicial, pois o órgão julgador pode responder a questionamento diferente em sua sentença.

Já a razão de decidir (ratio decidendi) caracteriza-se como o fundamento principal do raciocínio adotado pelo Tribunal, sendo, em síntese, a resposta à quaestio iuris. Deve ser a orientação geral daquele órgão para casos futuros similares, implicando em dever de coerência em sua jurisprudência (MENDES, 2013). Tanto a extração da quaestio iuris quanto da ratio decidendi não devem ser tão concretas que impossibilitem a sua aplicação futura, e nem tão abstratas a ponto de tornar sua utilização arbitrária.

Muitas vezes não há clareza nas disposições sobre o voto, bem como não parece também haver compromisso em se fixar uma ou outra corrente, sendo comum a adoção de determinada tese já posta na Corte, com adições, reduções ou, ainda, se silenciando diante de alguns pontos do debate. Vale mencionar que o Regimento Interno do STF contribui para esse cenário, o que pode ser observado, por exemplo, na autorização de elaboração dos votos anteriormente às sessões de julgamento, tornando-as muitas vezes mera leitura de argumentações prontas (MENDES, 2010), o que produz diversas decisões desconexas, sem diálogos entre si, dificultando a identificação de uma ratio decidendi única do Supremo.

Pretendendo superar esses obstáculos aos propósitos da pesquisa, as argumentações dos Ministros serão isoladas para, posteriormente, buscar a formação de um todo coerente (PRETZEL; KLAFKE, 2014, p. 89-104).

\footnotetext{
${ }^{2}$ Para exemplificar, o art. 927, I, do CPC/15 determina a vinculação das decisões do STF em sede de controle concentrado de constitucionalidade perante todo o Judiciário. Além disso, o art. 926 fixa o dever de uniformização, integridade e coerência de todo Tribunal em relação à sua jurisprudência.
} 
Em nossa análise, então, o método utilizado - com as modificações pertinentes à pesquisa, como retirada e aglutinamento de algumas classes, bem como acréscimo de outras - foi o modelo do Case Brief (DURAN, 2015):

Tabela 1 - Modelo de Case Brief

\begin{tabular}{|l|l|l|}
\hline Case Brief & Caso “A” & Caso “B” \\
\hline Classe Processual e № & & \\
\hline Relator & & \\
\hline Data de Julgamento & & \\
\hline Partes & & \\
\hline Dispositivos Questionados & & \\
\hline Fatos & & \\
\hline Quaestio Iuris & & \\
\hline Ratio Decidendi & & \\
\hline Decisão & & \\
\hline Voto Vencido e Fundamento & & \\
\hline Papel do STF & & \\
\hline
\end{tabular}

Fonte: Duran (2015)

Esse método materializa um raciocínio lógico para que se atinja a quaestio iuris do caso, tendo em vista abordar diversos elementos do feito e apresentar sua contextualização. Assim, traça um percurso que considera as particularidades do caso (classe processual, relator, data, partes, dispositivos e fatos), mas também congrega aspectos passíveis de maior generalização e que podem incidir sobre futuras ações (decisão, voto vencido e papel do STF).

A ratio decidendi, por sua vez, consiste na resposta da Corte a essa questão jurídica levantada, sendo determinada caso-a-caso por meio da somatória de todos os argumentos dos Ministros que compuseram a corrente vencedora de cada feito. Portanto, o problema deliberativo mencionado foi enfrentado da seguinte forma:

- os diferentes argumentos daqueles que votaram seguindo a vertente majoritária foram somados, necessariamente, ainda que não dialoguem entre si;

- os "Ministros silenciosos" (ou seja, aqueles que não anexaram as razões do voto mas apenas seguiram o Relator) tiveram seus votos igualados, argumentativamente, à decisão proferida por ele; 
- os que seguiram parcialmente a corrente vencedora terão seus argumentos somados à ela somente na parte em que a seguiram.

\subsection{Cláusula de Desempenho}

A ADI 966-4/DF trata de questão recorrente no âmbito do sistema partidário brasileiro: o desempenho eleitoral passado pode obstar a participação do partido na eleição subsequente?

Proposta pelo PSC (Partido Social Cristão) e relatada pelo Ministro Marco Aurélio, a ação direta em questão impugna dispositivos da Lei no $8.713 / 93$, criadores da chamada cláusula de desempenho ${ }^{3}$.

Essa cláusula impõe restrição à participação de organizações partidárias no processo eleitoral subsequente, baseada no seu desempenho no pleito antecedente. Ou seja, os partidos deveriam atingir determinado percentual de votos para ter a possibilidade de registrar candidatos às eleições majoritárias.

${ }^{3}$ Art. 5o Poderá participar das eleições previstas nesta Lei o partido que, até 3 de outubro de 1993, tenha obtido, junto ao Tribunal Superior Eleitoral, registro definitivo ou provisório, desde que, neste último caso, conte com, pelo menos, um representante titular na Câmara dos Deputados, na data da publicação desta Lei.

\$1º Só poderá registrar candidato próprio à eleição para Presidente e Vice-Presidente da República;

I - o partido que tenha obtido, pelo menos, cinco por cento dos votos apurados na eleição de 1990 para a Câmara dos Deputados, não computados os brancos e os nulos, distribuídos em, pelo menos, um terço dos Estados; ou

II - o partido que conte, na data da publicação desta Lei, com representantes titulares na Câmara dos Deputados em número equivalente a, no mínimo, três por cento da composição da Casa, desprezada a fração resultante desse percentual; ou

III - coligação integrada por, pelo menos, um partido que preencha condição prevista em um dos incisos anteriores, ou por partidos que, somados, atendam às mesmas condições.

\$2 Só poderá registrar candidatos a Senador, Governador e Vice-Governador:

I - o partido que tenha atendido a uma das condições indicadas nos incisos I e II do parágrafo anterior; ou

II - o partido que, organizado na circunscrição, tenha obtido na eleição de 1990 para a respectiva Assembleia ou Câmara Legislativa três por cento dos votos apurados, excluídos os brancos ou nulos; ou

III - coligação integrada por, pelo menos, um partido que preencha uma das condições previstas nos incisos I e II deste parágrafo, ou por partidos que, somados, atendam às mesmas condições. 
Assim, por um lado, o Requerente afirma que a cláusula de desempenho cria mais uma condição de elegibilidade em relação àquelas já previstas no art. 14, da Constituição Federal, de modo a também perpetrar tratamento desigual, violando o art. 5o, e infringir a autonomia partidária, assegurada pelo art. 17, do texto constitucional.

Por outro prisma, o Congresso Nacional, o Advogado-Geral da União e a Procuradoria-Geral da República alegam a inexistência de vedação constitucional à imposição de critérios por meio de lei ordinária a serem cumpridos pelos partidos, além de ressaltarem que as condições dizem respeito à capacidade da própria organização partidária e não do candidato, razão pela qual não deveria se falar em elegibilidade.

Considerando esse contexto, os Ministros decidiram da seguinte forma:

a) Min. Marco Aurélio (Relator): declara inconstitucionalidade da cláusula, que, ao restringir a atuação de alguns partidos, limitaria a representatividade de setores sociais incipientes ou até formalmente minoritários. Dessa forma, o pluripartidarismo e a representação das minorias ficariam prejudicados, sendo que diversos partidos seriam impossibilitados de participar das eleições.

Ademais, também consistiria uma incompatibilidade em face da autonomia partidária, pois acrescenta condição inexistente no texto constitucional, cuja disciplina não faz qualquer alusão à grandeza numérica da agremiação. Isso seria suficiente para demonstrar um ímpeto por parte do legislador ordinário em substituir o Constituinte em matéria já prevista;

b) Min. Francisco Rezek (divergente 1): julga parcialmente procedente a ação, deslocando a inconstitucionalidade apenas para o final do caput do art. 5ำ da Lei $n^{\circ} 8.713 / 93$, de modo a manter os filtros ao número excessivo de partidos ao mesmo tempo em que assegura a defesa das minorias. Isto é, argumenta que a Constituição estabeleceu liberdade quase irrestrita à criação de partidos, incumbindo à lei ordinária o papel de impor restrições. Nesse sentido, entender pela liberdade ampla sem quaisquer limites, constitucionais ou legais, significaria dar aval ao quadro caótico relativo ao número de agremiações políticas no Brasil - denominado hiperpartidarismo. 
No atinente à isonomia, ressalta a importância de identificar a existência, ou não, de razoabilidade na discriminação adotada; no entanto, considera a cláusula de desempenho razoável, pois não ofende a racionalidade, a moral ou qualquer valor jurídico relevante para atingir o fim ao qual se propõe.

A única ressalva do Ministro está relacionada à expressão final do art. $5^{\circ}$ impugnado: "desde que, neste último caso, conte com, pelo menos, um representante titular na Câmara dos Deputados, na data de publicação desta Lei”. Por se tratar da hipótese de registro provisório, alega que há ofensa ao princípio da igualdade em virtude da limitação imposta aos partidos minoritários, que ainda são incipientes no plano político, ao passo que vincular sua candidatura a tal regra prejudicaria seu nascimento originário;

c) Min. Ilmar Galvão: acolhe a declaração de inconstitucionalidade por se situar como mero intérprete da Constituição e não como legislador, ignorando o quadro fático em tela. O Ministro afirma que a restrição possui base estritamente pragmática de utilização dos horários de propaganda partidária gratuita, os quais não são dotados de proteção constitucional.

Ademais, traz à tona um confronto de valores: de um lado, a inexistência de norma constitucional que iniba a criação de critérios legais, o interesse público e o princípio da representatividade; e do outro, a igualdade, o pluripartidarismo, a liberdade da criação de partidos e a liberdade de voto. Sendo assim, determina que o segundo bloco leva larga vantagem, mas sem explicar as razões disso;

d) Min. Carlos Velloso: vota no mesmo sentido de Francisco Rezek, inclusive com a procedência parcial relativa ao final do art. 5을 da Lei $n^{0} 8.713 / 93$. Dessa forma, situa a relevância que as agremiações políticas possuem em uma democracia indireta, sendo imprescindível a liberdade partidária para tal. Entretanto, ressalta a necessidade da representatividade para concretizar o regime democrático, afastando as chamadas legendas de aluguel; assim, quando o art. 17, I, da Carta Magna fixa o caráter nacional como exigência aos partidos, autoriza o legislador ordinário a desenvolver seus mecanismos de aferição. 
Em outra linha, numa tentativa de minimizar as restrições impostas pela lei, lembra que os limites não recaem sobre o pleito proporcional, e, ainda, que é possível aos partidos se organizaram em uma coligação integrada por, no mínimo, uma agremiação que preencha os critérios de desempenho.

$\mathrm{Na}$ mesma toada de Rezek, porém, afirma que o final do art. 5은 ofende a isonomia por distinguir entre iguais (organizações partidárias com registro definitivo e provisório);

e) Min. Sepúlveda Pertence (divergente 2): inaugura uma nova corrente, declarando a total improcedência da arguição de inconstitucionalidade. Toma por base as repercussões positivas que a cláusula de desempenho teria no quadro partidário existente, resultando na sua racionalização moderada, já que a lei faculta opções para que os partidos cumpram as restrições impostas.

Como exemplo, cita o chamado Direito de Antena, consistente na prerrogativa das agremiações de participarem da divisão de tempo de radiofusão gratuita, e é considerado inviável se for admitido a grupos que nunca demonstraram inserção mínima no eleitorado.

Ademais, afirma que a liberdade de criação de partidos é distinta da extensão das prerrogativas outorgadas a cada agremiação no processo eleitoral, sendo esse o real assunto dos critérios de desempenho. Nesse sentido, afasta também a ofensa à isonomia, pois a distinção entre organizações partidárias com registro provisório e registro definitivo já é feita pela própria Lei Orgânica dos Partidos Políticos, de modo que os primeiros possuem um prazo para demonstrarem seu caráter nacional.

Por fim, ressalta o papel de legislador negativo do STF, devendo invalidar apenas os dispositivos violadores da Constituição Federal, o que não ocorre no caso, em sua visão;

f) Min. Sydney Sanches (divergente 3): introduz mais uma corrente à deliberação, de modo a declarar a inconstitucionalidade dos incisos e parágrafos do art. 5ำ da Lei no 8.713/93, mas a constitucionalidade de seu caput.

Primeiramente, o Ministro aduz a falta de qualquer fixação ou proibição constitucional de limites à atuação partidária, sendo papel da lei prevê-los. Além disso, também refuta qualquer ofensa 
à isonomia em razão da diferença existente entre partidos com registro provisório e com registro definitivo, pois estes já demonstraram seu caráter nacional e aqueles não.

$\mathrm{Na}$ sequência, apesar de demonstrar simpatia pela limitação do número de agremiações no jogo político, afirma a impossibilidade de admissão integral da cláusula de desempenho por violação à anterioridade da lei eleitoral. Isto é, o dispositivo teria partido de fatos já ocorridos (o desempenho dos partidos na eleição anterior) para regular o pleito futuro;

g) Min. Néri da Silveira: segue a decisão do Ministro Sydney Sanches ao declarar a inconstitucionalidade somente dos incisos e parágrafos do art. 5o impugnado, mantendo a integridade do caput. Os argumentos também são similares, porquanto identificar uma violação à anualidade da lei eleitoral, na medida em que diferencia norma estatutária (ou geral) de norma especial. Assim, a lei impugnada se enquadraria na categoria de norma especial, não podendo estabelecer exigências restritivas com base em informações já conhecidas acerca do processo eleitoral anterior.

Contudo, observa ofensa parcial à isonomia, ao passo que os incisos e parágrafos distinguem entre partidos já consolidados no meio político, resultando numa disparidade de chances, enquanto o caput apenas concretiza a diferença já prevista entre registro provisório e definitivo;

h) Min. Moreira Alves: acompanha os Ministros Sydney Sanches e Néri da Silveira, declarando inconstitucionais incisos e parágrafos do referido art. 5o, por se caracterizar como preceito "ad hoc" discriminador de fatos passados conhecidos, mas entendendo pela constitucionalidade do caput em razão de sua concordância com a Lei Orgânica dos Partidos Políticos;

i) Min. Octavio Gallotti (Presidente): apenas segue o voto do Ministro Sydney Sanches, que inaugurou a corrente.

Importa registrar que, após os debates e as declarações de votos, o Ministro Marco Aurélio aderiu ao posicionamento de Sydney Sanches, de modo a persistir na inconstitucionalidade dos incisos e parágrafos do art. 5을 da Lei $n^{\circ} 8.713 / 93$, mas alterar sua opinião relativa ao caput, que passou a julgar constitucional. Ainda: os Ministros Paulo Brossard e Celso de Mello não participaram do julgamento e nem anexaram seus votos ao acórdão. 


\subsection{Cláusula de Barreira}

Por meio das ADIs 1.351-3/DF e 1.354-8/DF, esta, apensa àquela, veicula-se a seguinte questão: é legítimo restringir a vida dos partidos a partir de seus resultados eleitorais?

No primeiro momento, observa-se estreita semelhança em relação ao caso anterior (a cláusula de desempenho), pois também se trata de norma com critérios limitadores do número de legendas. Entretanto, há uma diferença importante a ser destacada: enquanto aquela tratava da possibilidade de participar dos pleitos, esta se relaciona à participação das bancadas das agremiações políticas nas Casas Legislativas. Em outras palavras, o objetivo das normas impugnadas nos dois casos é o mesmo, bem como o critério adotado para tal, mas o aspecto das organizações partidárias atingido por elas é distinto.

Assim, os Requerentes, Partido Comunista do Brasil (PC do B), Partido Democrático Trabalhista (PDT) e outros, impugnaram o art. 13, e suas referências ${ }^{4}$, da Lei no 9.096/95 - denominada Lei dos Partidos Políticos.

De um lado, a inconstitucionalidade se funda na ofensa ao art. 5\%, caput e inciso XXXVI, da Constituição Federal, no atinente ao princípio da igualdade e às garantias do direito adquirido e ato jurídico perfeito. Ou seja: o dispositivo diferenciaria entre iguais, de modo a atuar em benefício de seus editores, enfraquecendo as minorias e demonstrando um projeto de perpetuação no poder. Além disso, a cláusula de barreira violaria o direito adquirido ao funcionamento parlamentar mediante o registro definitivo do partido perante o TSE, que constitui um ato jurídico perfeito. Por fim, o polo ativo aponta também uma incoerência com o art. 17, $₫ 1^{\circ}$, da Constituição, no qual está esculpida a autonomia partidária para definir seu funcionamento.

De outro lado, a Advocacia-Geral da União e o Procurador-Geral da República pugnam pela constitucionalidade da norma, afirmando sua compatibilidade com o art. 17, I, da Carta Magna, em relação à exigência

\footnotetext{
${ }^{4}$ Contidas no inciso II do art. 41, “caput” dos arts. 48 e 49 e inciso II do art. 57.

"Art. 13. Tem direito a funcionamento parlamentar, em todas as Casas Legislativas para as quais tenha elegido representante, o partido que, em cada eleição para a Câmara dos Deputados obtenha o apoio de, no mínimo, cinco por cento dos votos apurados, não computados os brancos e os nulos, distribuídos em, pelo menos, um terço dos Estados, com um mínimo de dois por cento do total de cada um deles."
} 
de caráter nacional para registro da agremiação. Nesse contexto, a cláusula apenas significaria uma verificação automática e periódica do cumprimento da regra constitucional, como forma de vedar a atuação de partidos sem expressiva representatividade.

Ante essa conjuntura, os Ministros votaram nos seguintes termos:

a) Min. Marco Aurélio (Relator): acolhe os pedidos da inicial e declara a inconstitucionalidade da cláusula de barreira, com base na defesa das minorias e nas consequências negativas aos partidos menores, tendo em vista que muitos deles seriam extintos. Isto é, além da vedação ao funcionamento parlamentar pelas agremiações que não atingiram os resultados previstos pelo art. 13, há também repercussões no fundo partidário e no tempo para propaganda partidária.

Dessa forma ${ }^{5}$, a repartição da verba do fundo partidário seria feita de acordo com a cláusula, ao passo que 99\% seriam rateados entre os partidos que cumpriram seu critério, e apenas 1\% destinado aos que não atenderam a essas condições. Além disso ${ }^{6}$, também possuiriam o espaço de somente dois minutos para propaganda eleitoral, em cada semestre, limitado à cadeia nacional.

Assim, o Ministro observa que a lei vedaria não só o funcionamento parlamentar aos partidos menores, mas, na prática, o acesso ao fundo partidário e à propaganda eleitoral, visto que apenas ${ }^{7}$ dos 29 partidos existentes à época cumpririam os requisitos legais. Nesse sentido, o Relator foca no esvaziamento da atuação das minorias por meio da cláusula de barreira, porquanto ela violaria a Constituição Federal ${ }^{8}$ no atinente ao pluralismo político. Asfixiar os partidos de menor representação implicaria prestigiar uma óptica nacional hegemônica e, portanto, uma ditadura da maioria. $\mathrm{O}$ Estado Democrático de Direito seria um instrumento de defesa dos direitos e liberdades fundamentais das minorias, entre elas a de representação política.

\footnotetext{
${ }^{5}$ Art. 41, II, da Lei no 9.096/95, no que toca à sua referência ao art. 13.

${ }^{6}$ Art. 48, da Lei no 9.096/95.

${ }^{7}$ Os partidos apontados no voto como tendo logrado atingir os ditames legais foram: PT, PMDB, PSDB, PFL, PP, PSB e PDT.

${ }^{8}$ Mais precisamente o art. 5, $\mathrm{V}$.
} 
Por fim, acaba não enfrentando, de fato, a conjuntura do número elevado de legendas, alegando que o enxugamento desse rol é automático, feito nas próprias urnas pela vontade do povo, e que descabe ao STF empunhar a bandeira do combate aos partidos de aluguel, sendo seu papel a defesa da Carta Magna;

b) Min. Ricardo Lewandowski: segue o voto do Relator, declarando a inconstitucionalidade da cláusula de barreira, sobretudo pela ofensa ao pluralismo político e à garantia de expressão das minorias.

O Ministro demonstra sua preocupação com o quadro fático, mas ressalta que a mera imposição de uma cláusula limitadora como essa não é a solução real e eficaz, devendo haver o desenvolvimento de reflexões mais amplas, e que tenham como pano de fundo a reforma política ${ }^{9}$. Assim, aduz que o pluripartidarismo está intrinsecamente vinculado à proteção de minorias, de modo que as restrições trazidas pelo art. 13, da Lei n⿳ำ 9.096/95 - colocadas como "draconianas" - ferem de morte tal princípio e privilegiam as organizações partidárias maiores. Consequentemente, acabam danificando a representatividade das minorias, impedindo que encontrem expressão no plano político.

c) Min. Cármen Lúcia: também acompanha a decisão do Relator, declarando a inconstitucionalidade em virtude da violação do pluralismo político, da representatividade essencial ao regime democrático, e do sufrágio como expressão da soberania popular.

A Ministra lembra que vivemos em um país plural, no qual a minoria de hoje deve possuir espaço para se tornar a maioria de amanhã, sendo que o multipartidarismo não é decorrência necessária do pluralismo. Com base nisso, foca no significado do voto, que não deve ser visto somente como um depósito em urna, mas, sim, parte de um processo mais amplo, que começa no prélio eleitoral e continua após as eleições, sendo concretizado com o funciona-

\footnotetext{
${ }_{9}^{9}$ Ao fazer referência à reforma política, o magistrado cita causas que foram posteriormente levadas ao próprio STF, como, por exemplo, a verticalização de coligações, outro objeto de estudo da monografia situado mais a frente.
} 
mento parlamentar ${ }^{10}$. Destarte, inibir esse funcionamento implicaria em retirar peso do voto, enfraquecer a representatividade e ofender as minorias. Ao final, enfrenta a questão fática sucintamente, afirmando que os partidos de aluguel não estão adstritos às agremiações menores, e a história comprova isso, ao passo que a solução encontrada pela cláusula violaria a proporcionalidade;

d) Min. Eros Grau: julga procedente a ADI, nos termos do voto do Ministro Marco Aurélio, reafirmando a ofensa ao pluralismo político e inserindo o princípio da igualdade de chances, como representação da isonomia. Outrossim, caracteriza a cláusula de barreira como "corredor da morte das minorias políticas" 11, pois estabelece valor diferente aos votos dos cidadãos, o que demonstraria seu caráter totalitário. Ademais, afronta a paridade de oportunidades ${ }^{12}$ na medida em que seria uma censura prévia à liberdade partidária, pois extingue partidos incipientes no cenário nacional, obstando que algum dia se tornem maioria;

e) Min. Carlos Britto: ratifica a corrente majoritária para entender pela procedência da ação direta. Assim, inicia seu voto sublinhando a dificuldade da questão colocada perante a Corte, de modo a sustentar a necessidade do exame da proporcionalidade em sentido estrito, isto é, qual decisão afirmaria mais valores constitucionais.

Nessa seara, afirma o peso maior dos argumentos empregados pelo Relator, ou seja, o pluralismo político, a liberdade associativa, a igualdade, o sufrágio e, por fim, a proteção das minorias. Como reforço a esse último valor, adiciona o prestígio por ele conferido ao mecanismo de freios e contrapesos, que deve operar não somente entre os Poderes, mas também no interior do Parlamento em si, assegurando espaço para atuação das minorias ${ }^{13}$.

${ }^{10}$ Em termos normativos, o art. 14 seria consolidado em conjugação com o art. 17, ambos do texto constitucional.

${ }^{11}$ A expressão é empregada em citação a uma palestra proferida por Marcello Cerqueira no congresso de Direito Constitucional ocorrido em novembro de 2006.

${ }^{12} \mathrm{O}$ Ministro faz alusão doutrinária a Carl Schmitt, segundo o qual a ausência do princípio da igualdade de chances conduziria a um projeto de perpetuação eterna no poder, pois a primeira maioria que o obtivesse o deteria para sempre.

${ }^{13}$ Para fortalecer sua tese, diz que "toda Constituição é um estatuto das minorias para que se faça uma oposição aos eventuais governantes". 
Ao final, em confronto à argumentação da AGU, lembra que a referência à lei feita pela Constituição em relação ao funcionamento parlamentar ${ }^{14}$ não permite a incompatibilidade legal com valores maiores da própria Carta Magna, o que caracterizaria hipótese de contradição performativa;

f) Min. Cezar Peluso: acompanha integralmente o Relator em sua declaração de inconstitucionalidade, no entanto, enfatiza que a ordem jurídica não recusa quaisquer espécies de cláusula de barreira, desde que prestigie o pluralismo simultaneamente à inibição do "multipartidarismo", pois essa fragmentação não protege as minorias.

Nessa seara, considera que a lei não atingiu esse objetivo, ofendendo ao pluripartidarismo ao restringir a atuação parlamentar, bem como o acesso ao rádio, televisão e ao fundo partidário, de modo a retirar prerrogativas inerentes à própria existência do partido.

Ao final, submete o dispositivo legal ao postulado da igualdade, afirmando a ausência de uma conexão jurídico lógica entre o critério de discriminação, e sua respectiva consequência, tendo em vista que tão somente o número de votos imputáveis a uma agremiação não é razoável;

g) Min. Gilmar Mendes: adota a posição majoritária de invalidação da cláusula de barreira sob os fundamentos da igualdade de chances, da defesa das minorias e da proporcionalidade.

Primeiramente, o Ministro expõe seu entendimento acerca da natureza dos partidos políticos, os quais considera instituições permanentes de participação política, estando integrados tanto à sociedade quanto ao Estado. Ressalta também uma particularidade do modelo brasileiro ${ }^{15}$, qual seja o de votação em lista aberta, que leva consigo o voto preferencial, isto é, a indicação de um candidato dentre os vários da legenda, que podem se eleger por arrastamento.

\footnotetext{
${ }^{14}$ A referência está alocada no art. $17, \mathrm{IV}$, quando afirma que "funcionamento parlamentar de acordo com a lei”. Contudo, o Ministro não considera a norma uma regra de eficácia limitada, mas apenas um chamamento à lei feito no plano instrumental, como modus operandi. ${ }^{15}$ Nesse sentido, cita Jean Blondel, para quem o modelo brasileiro seria "uma mistura de escrutínio uninominal e representação proporcional”. Isso significa que há um sincretismo entre a votação no próprio candidato e a eleição por meio do quociente eleitoral.
} 
Após essa introdução, o magistrado inicia um teste da cláusula perante o princípio da proporcionalidade ${ }^{16}$, chegando à conclusão de que aquela o infringe por conta do modo como foi positivada ${ }^{17}$. Ou seja, a vedação ao funcionamento parlamentar e as restrições excessivas ao tempo de propaganda partidária, bem como aos recursos do fundo partidário, significariam um "sacrifício radical das minorias".

Ademais, reforça o suposto atentado ao princípio da igualdade de oportunidades - sem o qual é impossível adotar uma concorrência livre e equilibrada no regime democrático - em decorrência de sua gradação excessiva. Dessa forma, o critério de "significação do partido", atingido por meio do desempenho eleitoral, teria sido exagerado, contribuindo para a manutenção do status quo em detrimento das minorias ${ }^{18}$.

Por fim, há também importantes referências a pautas futuras de julgamento no STF, como a fidelidade partidária e o financiamento privado de campanha, adiantando de parte de sua opinião sobre os temas;

h) Min. Sepúlveda Pertence: faz referência à cláusula de desempenho, que considera de "inconstitucionalidade chapada" por partir de dados concretos já conhecidos, em contraposição à cláusula de barreira, reguladora da diferenciação das agremiações a partir de desempenho futuro. Entretanto, integra a corrente dominante, apesar de reconhecer os problemas da proliferação exagerada de partidos sem significação social ou ideológica, porquanto não o julga suficiente para permitir tal tipo de solução.

\footnotetext{
${ }^{16}$ Emprega a proporcionalidade como "princípio da reserva legal proporcional”, o que implica dizer que a discricionariedade conferida ao legislador ordinário pelo mandamento constitucional (art. 17, IV) também deve se manter dentro de balizas proporcionais.

${ }^{17} \mathrm{O}$ Ministro enfatiza a possibilidade de se estabelecer uma cláusula de barreira, desde que adequada aos termos da ordem constitucional. Chega, inclusive, a esboçar uma proposta, ainda baseada em números, mas na qual o percentual de votação fosse requisito para a própria eleição de representantes, ficando ressalvado o acesso aos recursos necessários para competir no pleito seguinte - recursos que abrangem tanto a propaganda como o fundo partidário.

${ }^{18} \mathrm{Na}$ visão do juiz, "a minoria somente há de renunciar ao direito de resistência se ficar assegurada a possibilidade de vir a se tornar maioria”.
} 
O caminho encontrado pelo dispositivo legal seria ainda mais cruel do que seus similares no Direito Comparado, pois "não mata, deixa morrer", ao asfixiar os partidos menores quando retira sua atuação parlamentar e reduz a quantidades ínfimas seus recursos do fundo partidário, além de seu tempo de publicidade;

i) Min. Ellen Gracie (Presidente): se resume a seguir a unanimidade, razão pela qual seu voto será equiparado, argumentativamente, a tudo que foi apresentado por seus pares.

j) Min. Celso de Mello: há diversas referências a seu voto pelos outros Ministros durante os debates, entretanto, ele não foi anexado ao acórdão. Assim sendo, tendo em vista a unanimidade da decisão do Tribunal, seu voto também será equiparado ao da corrente composta por seus colegas.

Importa registrar que a declaração de inconstitucionalidade de todos os dispositivos que adotam os critérios da cláusula de barreira acabaria por extinguir as regras relativas à distribuição dos recursos do fundo partidário. Assim, há um debate que visa estender a eficácia de uma regra transitória ${ }^{19}$ reguladora desse aspecto, de modo que o STF acaba compondo uma norma ${ }^{20}$ através dos instrumentos constitucionais existentes - como a interpretação conforme e a própria declaração de inconstitucionalidade. Ainda: o Min. Joaquim Barbosa não participou do julgamento.

\section{O Presente}

Nessa seção apresentaremos a atualização da matéria sucintamente, ou seja, pretende-se aqui descrever o modo como a cláusula de barreira está inserida nas discussões parlamentares recentes.

A cláusula de barreira, atualmente, prevista no art. 3ํ, da PEC 36/2016, estabelece distinções em relação ao funcionamento parlamentar, criando duas espécies de partidos em razão dos resultados eleitorais: uma categoria composta por membros detentores de direito ao funcionamento, e outra sem a mesma prerrogativa.

Dessa forma, aqueles parlamentares que não atingirem o patamar erigido ainda gozarão de seus direitos de representação popular, o que

${ }^{19}$ Art. 57, caput, da Lei no 9.096/95.

${ }^{20} \mathrm{O}$ Ministro Gilmar Mendes chega a exigir atuação criativa da Corte, por meio de sentenças aditivas, que acredita serem a evolução do paradigma dogmático do legislador negativo. 
significa que conservarão seus mandatos, mas não terão direito ao funcionamento parlamentar, obstando a manutenção de estrutura própria e funcional nas casas legislativas, bem como o acesso ao fundo partidário, e à propaganda eleitoral na TV e no rádio, em mesma medida àqueles que alcançaram tal resultado.

Ademais, vale ressaltar que a proposição é também chamada comumente de "PEC da Reforma Política", pois, além da limitação ao número de partidos, aborda também o fim das coligações e a fidelidade partidária. Nessa seara, destacamos que, até pela delimitação do recorte de pesquisa, o tema em discussão no artigo será apenas um escopo da proposta (cláusula de barreira), mas seu destino é central para a integralidade da reforma política.

A alteração constitucional, durante o desenvolvimento deste artigo, se encontrava em tramitação na Câmara dos Deputados - renumerada como PEC no 282/2016 - com parecer favorável aprovado perante a Comissão de Constituição, Justiça e Cidadania (CCJC), aguardando a elaboração de parecer da Comissão Especial.

Contudo, já é possível extrair das discussões legislativas ${ }^{21}$ a semelhança em relação ao debate travado no bojo das ADIs 966-4/DF (cláusula de desempenho), 1.351-3/DF e 1.354-8/DF (ambas tratando da cláusula de barreira), ou seja, a dicotomia entre operacionalizar melhor a disputa democrática brasileira a partir de uma diminuição do fenômeno do hiperpartidarismo, ou preservar a estrutura vigente como garantia de representação das minorias.

Além das demais modificações trazidas pela proposta, como o fim das coligações em eleições proporcionais e a positivação da fidelidade

${ }^{21} \mathrm{O}$ contraste de argumentos pode ser observado na comparação dos votos em separado proferidos na tramitação do projeto perante a CCJC e o parecer do Relator, acolhido pela maioria dos parlamentares membros da Comissão. Cf. Parecer do Relator Deputado Betinho Gomes. 04 abr. 2017. Disponível em: <http://www.camara.gov.br/ proposicoesWeb/prop_mostrarintegra?codteor $=1541803 \&$ filename $=$ PRL $+1+C C J C+\%$ 3D\%3E+PEC+282/2016>. Acesso em: 14 maio 2017.

Voto em separado: Deputados Chico Alencar e Ivan Valente. 11 abr. 2017. Disponível em: <http://www.camara.gov.br/proposicoesWeb/prop_mostrarintegra?codteor $=1544395 \&$ filename $=\mathrm{VTS}+1+\mathrm{CCJC}+\% 3 \mathrm{D} \% 3 \mathrm{E}+\mathrm{PEC}+282 / 2016>$. Acesso em: 14 maio 2017. 
partidária, o texto guarda critério idêntico aos elaborados em momentos anteriores de nossa história constitucional. Em outros termos: o projeto apresenta o patamar mínimo de $2 \%$ de votos válidos, distribuídos em 14 unidades da Federação - com o mínimo de $2 \%$ em cada uma delas -, para as eleições de 2018 , e $3 \%$ a partir de $2022{ }^{22}$.

O parâmetro adotado pela proposição ainda é o desempenho eleitoral, de forma semelhante às duas outras cláusulas de que trata este texto. Em relação à cláusula de desempenho a diferença é maior, tendo em vista que aquela impedia os partidos de participarem do próprio pleito, o que não ocorre com a atual proposta. Já no atinente à antiga cláusula de barreira, a distinção está localizada tão somente no percentual determinado como mínimo a ser atingido, que foi flexibilizado para se tornar menos exigente.

Se, por um lado, a PEC é apontada como elemento necessário na busca do objetivo de inibir a formação dos chamados "partidos de aluguel", cuja proliferação seria um dos fundamentos para o enfraquecimento da disputa ideológica no jogo democrático do país, por outro sofre críticas ligadas ao cerceamento de representação das minorias políticas, porquanto - conforme afirmado pelas manifestações divergentes -21 partidos ficariam sem funcionamento ${ }^{23}$.

${ }^{22}$ Art. 1ํ A Constituição Federal passa a vigorar com as seguintes alterações: 'art 17. \2º Os partidos políticos, após adquirirem personalidade jurídica, na forma da lei civil, registrarão seus estatutos no Tribunal Superior Eleitoral, e terão direito a funcionamento parlamentar aqueles que obtiverem, nas eleições para a Câmara dos Deputados, no mínimo 3\% (três por cento) dos votos válidos, distribuídos em pelo menos 14 (quatorze) unidades da Federação, com um mínimo de $2 \%$ (dois por cento) dos votos válidos em cada uma destas'.

Art. $3^{\circ}$ Art. $3^{\circ}$ As restrições ao funcionamento parlamentar dos partidos políticos previstas nos $\iint 2^{\circ}, 3^{\circ}$ e $6^{\circ}$ do art. 17 da Constituição Federal aplicar-se-ão a partir das eleições de 2022.

Parágrafo único. Nas eleições de 2018, as restrições de que trata o caput se aplicarão aos partidos políticos que não obtiverem, nas eleições para a Câmara dos Deputados, no mínimo $2 \%$ (dois por cento) dos votos válidos, distribuídos em pelos menos 14 (quatorze) unidades da Federação, com um mínimo de $2 \%$ (dois por cento) dos votos válidos em cada uma destas.

${ }^{23}$ Esses dados estão baseados nos resultados eleitorais extraídos do pleito de 2014. Cf. Voto em Separado: Deputado Rubens Pereira Jr. 11 abr. 2017. Disponível em: <http:// www.camara.gov.br/proposicoesWeb/prop_mostrarintegra?codteor $=1544448 \&$ filename $=\mathrm{VTS}+2+\mathrm{CCJC}+\% 3 \mathrm{D} \% 3 \mathrm{E}+\mathrm{PEC}+282 / 2016>$. Acesso em: 14 maio 2017. 


\section{O Futuro}

Para iniciar a análise do eventual destino da nova cláusula de barreira no Supremo Tribunal Federal é importante que consideremos não apenas os novos integrantes da Corte, mas também a opinião daqueles Ministros que já se manifestaram publicamente, afirmando, implícita ou explicitamente, que - de alguma maneira - demonstraram uma espécie de arrependimento da decisão prolatada. Esses parecem ser os casos dos ministros Gilmar Mendes e Ricardo Lewandowski.

Quanto ao primeiro, o Ministro do STF e Presidente do TSE, manifestou expressamente sua visão no sentido de que o Supremo teria falhado na declaração de inconstitucionalidade da proposição normativa, e feito uma intervenção indevida no domínio legislativo. Ele argumenta que a inovação é essencial para reduzir o número crescente de partidos políticos no país e, então, aumentar a representatividade (PASSARINHO, 2013).

O Ministro Lewandowski, por sua vez, também afirmou publicamente sobre a necessidade de cláusula de barreira em substituição à invalidada pelo Tribunal, de modo a reconhecer implicitamente o erro naquela decisão. Sua argumentação vai na linha de que o dispositivo constitucional que prevê a livre e ampla criação de partidos deve ser respeitado, mas isso não significaria dar aval à criação desenfreada de legendas, dificultando a governabilidade e permitindo a existência de entidades que sequer possuem um mínimo de lastro popular (PASSARINHO, 2013).

Desde a última decisão do Tribunal na matéria no ano de 2006, já se passaram mais de 10 anos e, com isso, houve a mudança na composição do STF com a saída e ingresso de alguns ministros. De modo mais específico, os magistrados que não figuraram naquela ocasião foram: Rosa Weber, Luiz Fux, Dias Toffoli, Luis Roberto Barroso, Luis Edson Fachin e Alexandre de Moraes.

De início, destacamos que não conseguimos encontrar posicionamentos públicos dos Ministros Fachin e Luiz Fux a respeito do tema, bem como da Ministra Rosa Weber. Contudo, relativamente aos demais recém-detentores do cargo, há manifestações acadêmicas e perante a imprensa que demonstraram publicamente sua posição e, portanto, pode revelar uma tendência de cada voto. 
Nesse sentido, vale mencionar que o Ministro Barroso talvez seja o que mais tenha abordado a cláusula de barreira em suas palestras e artigos. Sua posição é enfática pela necessidade de profunda reforma política, abrangendo a adoção do sistema distrital misto, o semipresidencialismo, a fidelidade partidária e a contenção da pulverização partidária por meio de uma barreira. Quanto ao último aspecto - que aqui nos interessa - defendeu por diversas vezes sua implementação como forma de inibir a proliferação de partidos sem lastro popular, o que encareceria as eleições, além de impedir a consolidação de identidade programática nos pleitos (MARTINES, 2016).

O Ministro Dias Toffoli também parece seguir essa linha, sendo favorável a modificações no sistema eleitoral brasileiro que vão desde o fim das coligações até a criação da cláusula de barreira, de modo a identificar uma falha da Corte em sua decisão passada. O Ministro, no entanto, diferencia tecnicamente esse modelo da chamada cláusula de desempenho, na qual não se obsta o acesso às cadeiras do parlamentar eleito, mas impede que o partido de tal representante eleito tenha liderança, e que o parlamentar integre qualquer Comissão de sua casa legislativa. Assim, alega que a inconstitucionalidade recai sobre o desempenho, mas não sobre a barreira, adotada em outros países como a Alemanha (REVISTA CONSULTOR JURÍDICO, 2017).

Por fim, resta observarmos as manifestações públicas sobre o tema do mais recente Ministro do Supremo, Alexandre de Moraes, o qual já havia dado demonstrações acadêmicas de apoio à restrição (MORAES, 2013), e que continuou a se manifestar dessa forma em sua própria sabatina (AGÊENCIA SENADO, 2017). Afirmou, ainda, que a cláusula deve ser implementada com o fito de impedir a formação de legendas de aluguel, cujo efeito mais nefasto é o aumento no distanciamento entre representantes e representados. Além disso, entendeu que os precedentes da Corte relacionados à matéria são ilegítimos, tendo usurpado competência do legislador.

\section{Considerações Finais}

Embora não seja possível determinar o posicionamento que o Supremo Tribunal Federal adotaria, caso a cláusula de barreira seja aprovada e tenha sua constitucionalidade questionada, é possível trazer algumas conclusões a respeito da presente pesquisa descritiva. 
Considerando a composição atual do STF e o tema da cláusula de barreira pode-se projetar o seguinte quadro:

\begin{tabular}{|c|l|}
\hline Ministro & \multicolumn{1}{|c|}{ Status } \\
\hline Celso de Mello & $\begin{array}{l}\text { Se manifestaram em decisão no STF contra a } \\
\text { cláusula de barreira e, durante a pesquisa, não en- } \\
\text { contramos manifestações públicas que indicaram } \\
\text { sua mudança de posicionamento. }\end{array}$ \\
\hline Marco Aurélio & $\begin{array}{l}\text { Se manifestaram em decisão no STF contra a cláu- } \\
\text { sula de barreira, mas encontramos manifestações pú- } \\
\text { blicas que indicaram a mudança de posicionamento } \\
\text { sendo favoráveis à cláusula de barreira. }\end{array}$ \\
\hline Gilmar Mendes & $\begin{array}{l}\text { Não se manifestaram em decisão no STF contra } \\
\text { a cláusula de barreira, mas encontramos mani- } \\
\text { festações públicas que indicaram ser favoráveis à } \\
\text { cláusula de barreira. }\end{array}$ \\
\hline Ricardo Lewandowski & $\begin{array}{l}\text { Não se manifestaram em decisão no STF contra } \\
\text { a cláusula de barreira e, durante a pesquisa, não } \\
\text { encontramos manifestações públicas que indica- } \\
\text { ram seu posicionamento. }\end{array}$ \\
\hline Diaberto Barroso Toffoli & \\
\hline Edexandre de Moraes Fachin &
\end{tabular}

Quadro 1 - Posicionamento do STF sobre a cláusula de barreira

Fonte: Elaborado pelo autor.

Essa contextualização pretende fornecer ao leitor alguns rumos possíveis que o tema poderá tomar diante da coerência estabelecida anteriormente nas decisões do Supremo Tribunal Federal ou, então, pode colaborar para aferir a tendência de um distinguishing ${ }^{24}$ ou overruling ${ }^{25}$ em sua jurisprudência.

Dentre tantas abordagens que o tema da cláusula de barreira suscita, procurou-se aqui apresentar abordagem descritiva, com o intuito de colaborar com o desenvolvimento de novas pesquisas no tema e com o amadurecimento da pesquisa empírica em direito.

${ }^{24}$ Distinguishing: diz-se de um caso excepcional na jurisprudência do Tribunal, no qual, dada a excepcionalidade, não se tem o condão de refletir mudança de posição ou quebra de coerência daquele órgão.

${ }^{25}$ Overruling: mudança da opinião da Corte e que normalmente exige maior esforço argumentativo para se estabelecer sem ferir a segurança jurídica.

Resenha Eleitoral (Florianópolis), v. 21, n. 1, p. 95-118, nov. 2017 


\section{Referências}

AGÊNCIA SENADO. Moraes: STF 'substituiu legislador' ao derrubar cláusula de barreira para partidos. Senado Notícias, 21 fev. 2017. Disponível em: <http://www12.senado.leg.br/noticias/materias/2017/02/21/moraes-stf-substituiu-legislador2019-ao-derrubar-clausula-de-barreira-para-partidos $>$. Acesso em: 14 maio 2017.

BARROSO, Luís Roberto. A Reforma Política: uma proposta de sistema de governo, eleitoral e partidário para o Brasil. Instituto Ideias. Disponível em: $<$ https://edisciplinas.usp.br/pluginfile.php/1604367/mod_resource/content $/ 1 /$ Texto $\% 20$ Barroso $\% 20$ Sistema $\% 20$ de $\% 20$ GGovern $\% 2 \mathrm{C} \% 20$ eleitoral\%20e\%20partid\%C3\%A1 rio.pdf>. Acesso em: 14 maio 2017.

DE FARIAS, P. H. E. O Fiel da Balança: O Quebra-cabeça dos Partidos Políticos na Jurisprudência do STF como Garantia das Regras do Jogo Democrático. Disponível em: <http://www.sbdp.org.br/ver_monografia. php?idMono=302>. Acesso em: 20 jun. 2017.

DURAN, C. V. Como ler decisões judiciais?, Ejur Participativo Direito FGV, Dez. 2015. Disponível em: < http:// jurparticipativo.direitosp.fgv.br/ portfolio/como-ler-decisoes-judiciais>. Acesso em: 26 out. 2016.

DWORKIN, R. Uma questão de princípio. São Paulo: Martins Fontes, 2007.

HAJE, Lara; NOBRE, Noéli. Gilmar Mendes diz que STF errou em decisão sobre cláusula de barreira. Câmara Notícias, 21 mar. 2017. Disponível em: <http://www2.camara.leg.br/camaranoticias/noticias/POLITICA/ 526598-GILMAR-MENDES-DIZ-QUE-STF-ERROU-EM-DECISAO-SOBRE-CLAUSULA-DE-BARREIRA.html>. Acesso em: 20 jun. 2017.

MARTINES, Fernando. Barroso defende cláusula de barreira para evitar a proliferação de partidos. Revista Consultor Jurídico, 2016. Disponível em: $<$ http://www.conjur.com.br/2016-mai-17/barroso-defende-clausula-barreira-excesso-partidos>. Acesso em: 14 maio 2017.

MENDES, C. H. Onze Ilhas. Folha de São Paulo, 2010, p. 3. .Lendo uma decisão: obiter dictum e ratio decidendi. Racionalidade e retórica na decisão. Sociedade Brasileira de Direito Público, 2013. Disponível em: < http://www.sbdp.org.br/ arquivos/material/19_Estudo\% 20dirigido $\% 20-\% 20$ Ratio $\%$ 20decidendi $\% 20 \mathrm{e} \% 20$ obter $\%$ 20dictum $\% 20-\% 20$ Conrado\% 20Hubner\%20Mendes.pdf>. Acesso em: 12 out. 2016. 
MORAES, Alexandre de. "Cláusula de desempenho" fortalece o sistema eleitoral. Revista Consultor Jurídico, 2013. Disponível em: <http://www. conjur.com.br/2013-nov-08/justica-comentada-clausula-desempenho-fortalece-sistema-eleitoral>. Acesso em: 14 maio 2017.

PASSARINHO, Nathalia. Lewandowski defende cláusula de barreira contra excesso de partidos. G1, 1 out. 2013. Disponível em: <http://g1.globo.com/ politica/noticia/2013/10/lewandowski-defende-clausula-de-barreira-contra-excesso-de-partidos.html>. Acesso em: 20 jun. 2017.

PRETZEL, B. R.; KLAFKE, G. F. Processo decisório no Supremo Tribunal Federal: aprofundando o diagnóstico das onze ilhas. Revista de Estudos Empíricos em Direito, vol. 1, n. 1, jan 2014. p. 89-104.

REVISTA CONSULTOR JURÍDICO. Toffoli defende criação de cláusula de barreira e fim de coligações partidárias. 20 abr. 2017. Disponível em: $<$ http://www.conjur.com.br/2017-abr-20/toffoli-defende-criacao-clausula-barreira-fim-coligacoes>. Acesso em: 14 maio 2017.

Diogo Rais - Mestre e Doutor em Direito do Estado pela PUC-SP. Professor da Faculdade de Direito da Universidade Presbiteriana Mackenzie. Pesquisador da Escola de Direito de São Paulo da Fundação Getúlio Vargas.

Pedro Henrique Espagnol de Farias - Graduando em Direito pela PUC-SP. Ex-aluno da Escola de Formação Pública da SBDP. 
